\title{
Sediment Enrichment Ratio and Nutrient Leached by Runoff and Soil Erosion on Cacao Plantation
}

\author{
Oteng Haridjaja \\ Soil Sciences and Land Resources Department, Faculty of Agriculture, Bogor Agricultural University. \\ Darmaga, Bogor 16680, Indonesia, e-mail: oteng_haridjaja@yahoo.com
}

Received 15 May 2009 / accepted 15 August 2011

\begin{abstract}
Soil consevation management system is an activity for diminishing sediment enrichment ratio and nutrient leacheds by water run off and soil erosion processes. The research was aimed to study sediment enrichment ratio and nutrient leached by run off and soil erosion on cacao plantations. Arachis pintoi with strips parallel contour and multiple strip cropping of upland rice or soybean (Glycine max) were planted to improve soil physical characterictic on cacao plantation as a main plant. The expriment were conducted with treatments as 10-15\% and 40-45\% slopes, 5-7 months and 25-27 months cacao ages (as main plants). As sub plots are T1 as a monoculture which to be cleaning under the plant canopy, T2 as a multiple strip cropping of upland rice or soybean, T3 as a combination of T2 and $A$. Pintoi strip. The results showed that total $\mathrm{N}, \mathrm{P}_{2} \mathrm{O} 5$, and $\mathrm{K}_{2} \mathrm{O}$ and organic-C contents in water run off and soil sediments indicated that T3 > T2 > T1 treatment, with the contents of each nutrient: T3 (total N $0.18 \% ; 24.87 \mathrm{mg} 100$

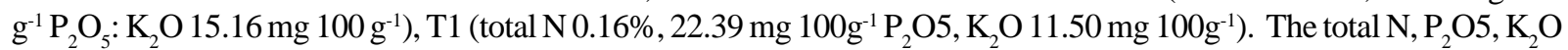
and organic-C soil contents < accumulation nutrient contents of total water run off and soil sediment transport. All of treathments have sediment enrichment ratios $>1$.
\end{abstract}

Keywords: Cacao, nutrient leached, run off, SER, soil erosion, strip cropping

\section{INTRODUCTION}

Cacao as a main agricultural product in the province of South East Sulawesi is planted in slop areas. According to the data in 2000 , this plantation occupies about 113,276 ha of area and its mean productivity is about $225 \mathrm{~kg} \mathrm{ha}^{-1}$ (Wahab et al. 2002). This productivity is lower than its normal potential productivity (2-3 $\mathrm{Mg}$ dry-seed $\mathrm{ha}^{-1} \mathrm{yr}^{-1}$ ). This is due to not property use of soil and water conservation technique and land management practice. Young plants have a narrow canopies that causes soil surface to be unprotected from the aggression of rainfall kinetic energy. As a result, run-off and erosion head to the surface land degradation. The run-off/erosion may contain sediment and dissolved nutrients, and other contamination which can reduce the water quality. These nutrient contents are essentially depend on the agro-technology used in the production process or land use management. The nutrients will be transported to the water bodies by the respective rivers, and in turn, enrich the surface water. The consequences, the growth of aquatic vegetations on

J Trop Soils, Vol. 17, No. 1, 2012: 67-74

ISSN 0852-257X water surface is inhibited and water quality is degraded. The seriousness of the chemical contamination of surface water or ground water in threatening human life is not yet known due to the lack of available data (Sinukaban 2007).

In view of the food shortage in tropical area, the question most often asked is whether soil productivity in tropical environments can be sustained with intensive and continuous farming. many research indicate that most tropical soils can be intensively cultivated and produced high and sustained yield when an ecological approach to agriculture is adopted (Sinukaban 2007a).

Multiple cropping technology is a good method for land management and vegetative soil and water consevations. It can protect land surface, improve soil condition, increase water infiltration rate, and decrease nutrient leached by run-offs and erosions. For an effective implementation of this technology using new approaches so that the problems can be readily resolved in the field, we did an exact calculation based on the approaches of environmental biophysics, economic, social and institutional conditions (Alvim 1977; Zuidema et al. 2005). In this study, we used the multiple cropping technology of cacao + dry land-rice + Arachis pintoi's strip with contour, or cacao + soybeans + Arachis pintoi's strip with contour as treatments. 
The objective of this study was to determine the influence of these treatments to soil Sediment Enrichment Ratio SER (Arsyad 2010) and nutrient leached by run-off and soil erosion at the cacao plantation.

\section{MATERIALS AND METHODS}

This study was conducted in cacao plantation in the field on Typic Hapludult (according to soil taxonomy determination method by Suwardi and Wiranegara 2000; Abdullah 2006) in Amosilu, Besulutu Sub-District, Konawe District, in the province of South East Sulawesi. Soil and water samples were analyzed in the laboratory (Table 1). Rainfall intensity was about $<2000 \mathrm{~mm} \mathrm{yr}^{-1}$ with high fluctuation of monthly average rainfall distribution.

\section{Research Methodology}

The experiment was done in a split plot randomized completely block design with three replicates (Mattjik dan Sumertajaya 2002). Three factors were used as treatment: two slopping area percentages, two cacao plant ages, and three conditions of vegetative soil and water conservation techniques such as: $10-15 \%$ (L1) and 40-50\% (L2) of slopping area; 5-7 months (U1) and 25-27 months (U2) of plant age; and cacao-monoculture with weeding practice (T1), upland rice + soybeans between main cacao plants (T2); T2 + Arachis pintoi strip (T3). Combinations of slopping area + cacao plant age factors were package as main plots of treatments: $\mathrm{L} 1 \mathrm{U} 1=\mathrm{P} 1, \mathrm{~L} 1 \mathrm{U} 2=\mathrm{P} 2, \mathrm{~L} 2 \mathrm{U} 1=$ $\mathrm{P} 3$, and L2U2 = P4. The combinations of treatments were P1T1, P1T2, P1T3, P2T1, P2T2, P2T3, P3T1, P3T2, P3T3, P4T1, P4T2, P4T3. So

Table 1. Nutrient analyzed methods of soil, sediment and water samplings in this study (Sutandi 2006).

\begin{tabular}{ll}
\hline Kind of nutrients & Methods \\
\hline Soil and sediment & \\
$\mathrm{P}_{2} \mathrm{O}_{5}$ & $\mathrm{HCl} 25 \%$-extraction \\
$\mathrm{K}_{2} \mathrm{O}$ & $\mathrm{HCl} 25 \%$-extraction \\
Organic-C & Walkley and Black \\
Run-off & \\
$\mathrm{NH}_{3}, \mathrm{NO}_{3}$, and $\mathrm{NO}_{2}$ & Blue-indophenol and \\
& brusin \\
$\mathrm{PO}_{4}$ & Blue-molibdenol \\
Total-K & Flame-photometry \\
Organic-C & Permangatometry \\
\hline
\end{tabular}

far, there was $2 \times 2 \times 3 \times 3=36$ combinations of treatment.

\section{Activity Stages}

Research location was chosen based on the criteria of cacao plant ages and slopping areas. Horizon descriptions of soil profile sample were determined in the field. Construction of erosion and water plot measurements: $10 \mathrm{~m} \times 5 \mathrm{~m}$ on two slopping area with two plant ages were done in the field (modified method of Wischmeier and Smith 1978). Sediment and run-off sample measurements were done in the field and the removal of sediment and water sampling was analyzed in the laboratory. Removal of soil surface experiment plot samplings was done at the end of the experiments (Cut).

Calculating Sediment Enrichment Ratio (SER) (Arsyad 2010) is as follow :

$$
\mathrm{SER}=\mathrm{Cus} / \mathrm{Cut}
$$

Cus $=$ Nutrient concentration $(\mathrm{N}, \mathrm{P}, \mathrm{K}$ or Organic matter) of sediment transported by run-off.

Cut $=$ Nutrient concentration of inheritance of soil surface.

\section{Data Analyses}

The mathematic model used in this study is Yijk $=\mathrm{u}+\mathrm{Bk}+\mathrm{Pi}+\mathrm{Dik}+\mathrm{Tj}+\mathrm{PiTj}+\mathrm{Eijk}$ with the analyses of variance (ANOVA) using SAS program (Mattjik and Sumertajaya 2002) and means test with Honest Significance Different (HSD) 0.05.

\section{RESULTS AND DISCUSSIONS}

\section{Total $\mathbf{N}$ of soil and sediment}

The total $\mathrm{N}$ contents of soil and sediment as a response to treatment are presented in Table 2 .

The results of the analysis of variance from the treatment given, whether through the treatment of conservational measures (T) or the treatment of plant age/slope $(\mathrm{P})$ showed significant effect $(\mathrm{P}<$ $0.05)$ on total $\mathrm{N}$ of the soil and sediments. The highest soil total $\mathrm{N}$ was in the treatment of T3 (0.22) and P4 (0.21), but there was no interaction between them. The lowest soil total $\mathrm{N}$ was in the treatment of T1 (0.16) and P1/P2 (0.17).

Treatments that provided the highest total $\mathrm{N}$ of soil (T3 and $\mathrm{P} 4$ ) also provided the highest total $\mathrm{N}$ of sediment (0.22 and 0.23). However, the total $\mathrm{N}$ of sediment was higher than the total $\mathrm{N}$ of soil. This was due to the eroded sediment or soil of the topsoil which was known for its richness in nutrients and organic matters, causing the nutrients contained in them were to be higher than the nutrient in the soil which left behind. 
Table 2. Total $\mathrm{N}$ contents in soil and sediment as a response to soil conservation treatment.

\begin{tabular}{|c|c|c|c|c|}
\hline Treatments & T1 & $\mathrm{T} 2$ & T3 & Average \\
\hline \multicolumn{5}{|c|}{.. Total $\mathrm{N}$ of soil $(\%)$} \\
\hline P1 & 0.14 & 0.18 & 0.20 & $0.17 \mathrm{~b}$ \\
\hline $\mathrm{P} 2$ & 0.15 & 0.16 & 0.20 & $0.17 \mathrm{~b}$ \\
\hline P3 & 0.17 & 0.18 & 0.23 & $0.19 \mathrm{a}$ \\
\hline $\mathrm{P} 4$ & 0.18 & 0.21 & 0.25 & $0.21 \mathrm{a}$ \\
\hline Average & $0.16 \mathrm{~b}$ & $0.18 \mathrm{ab}$ & $0.22 \mathrm{a}$ & \\
\hline \multicolumn{5}{|c|}{ Total Total $\mathrm{N}$ of sediment $(\%)}$. \\
\hline $\mathrm{P} 1$ & 0.10 & 0.10 & 0.11 & $0.10 \mathrm{c}$ \\
\hline $\mathrm{P} 2$ & 0.11 & 0.07 & 0.11 & $0.10 \mathrm{c}$ \\
\hline P3 & 0.31 & 0.20 & 0.30 & $0.27 \mathrm{~b}$ \\
\hline P4 & 0.30 & 0.28 & 0.37 & $0.32 \mathrm{a}$ \\
\hline Average & $0.20^{\mathrm{a}}$ & $0.16 \mathrm{~b}$ & $0.22 \mathrm{a}$ & \\
\hline
\end{tabular}

Note: The mean values in the same column and row followed by the different letter indicates significantly different (P > 0.05). $\mathrm{T} 1$ = cacao-monoculture with weeding practice, $\mathrm{T} 1=$ dry land-rice + soybeans between main cacao plants, and T3 + A. pintoi strip. $\mathrm{P} 1=$ slope $10-15 \%$ and 5-7 months, $\mathrm{P} 2=$ slope $10-15 \%$ and $25-27$ months, $\mathrm{P} 3$ $=40-50 \%$ and $5-7$ months, and $\mathrm{P} 4=40-50 \%$ and $25-27$ months.

\section{$\mathrm{NH}_{3}, \mathrm{NO}_{3}$, and $\mathrm{NO}_{2}$ of Run Off}

Run off (RO) contains compounds that are dissolved in it, including $\mathrm{NH}_{3}, \mathrm{NO}_{3}$, and $\mathrm{NO}_{2}$. These compounds are transported along the RO, which can potentially reduce soil fertility.

The $\mathrm{NH}_{3}, \mathrm{NO}_{3}$, and $\mathrm{NO}_{2}$ contents of $\mathrm{RO}$ in each treatment are presented in Table 3. The results of the analysis of variance and HSD test in Table 3 shows that the treatment of conservational measures $(\mathrm{T})$ and the treatment of plant age/slope (P) had no significantly effect $(\mathrm{P}<0.05)$ on the $\mathrm{NH}_{3}$ content of RO. In contrast to the $\mathrm{NO}_{3}$ and $\mathrm{NO}_{2}$ contents, the treatment of conservational measures had significantly effect on the $\mathrm{NO}_{3}$ content

Table 3. The $\mathrm{NH}_{3}, \mathrm{NO}_{3}$, and $\mathrm{NO}_{2}$ content of $\mathrm{RO}$ in each soil conservation treatment.

\begin{tabular}{|c|c|c|c|c|}
\hline Treatments & $\mathrm{T} 1$ & $\mathrm{~T} 2$ & T3 & Average \\
\hline & \multicolumn{4}{|c|}{ 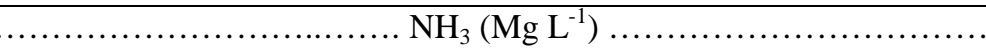 } \\
\hline P1 & 0.047 & 0.038 & 0.053 & $0.045 \mathrm{a}$ \\
\hline $\mathrm{P} 2$ & 0.055 & 0.056 & 0.052 & $0.054 \mathrm{a}$ \\
\hline P3 & 0.047 & 0.063 & 0.057 & $0.056 \mathrm{a}$ \\
\hline P4 & 0.054 & 0.049 & 0.056 & $0.053 \mathrm{a}$ \\
\hline \multirow[t]{2}{*}{ Average } & $0.058 \mathrm{a}$ & $0.042 \mathrm{a}$ & $0.054 \mathrm{a}$ & \\
\hline & \multicolumn{4}{|c|}{$\ldots \ldots \ldots \mathrm{NO}_{3}\left(\mathrm{Mg} \mathrm{L}^{-1}\right) \ldots \ldots \ldots$} \\
\hline P1 & $5.89 \mathrm{~cd}$ & $5.84 \mathrm{~cd}$ & $4.65 \mathrm{e}$ & $5.46 \mathrm{a}$ \\
\hline $\mathrm{P} 2$ & $6.04 \mathrm{~b} \mathrm{~cd}$ & $8.23 \mathrm{a}$ & $5.32 \mathrm{ed}$ & $6.53 \mathrm{a}$ \\
\hline P3 & $5.84 \mathrm{~d}$ & $5.45 \mathrm{ed}$ & $7.17 \mathrm{ba}$ & $6.03 \mathrm{a}$ \\
\hline $\mathrm{P} 4$ & $5.99 \mathrm{~cd}$ & $7.17 \mathrm{ba}$ & $6.67 \mathrm{bc}$ & $6.61 \mathrm{a}$ \\
\hline \multirow[t]{2}{*}{ Average } & $5.85 \mathrm{~b}$ & $6.67 \mathrm{a}$ & $5.95 \mathrm{~b}$ & \\
\hline & \multicolumn{4}{|c|}{$\ldots \ldots \ldots \mathrm{NO}_{2}\left(\mathrm{Mg} \mathrm{L}^{-1}\right) \ldots \ldots$} \\
\hline P1 & $0.07 \mathrm{ba}$ & $0.05 \mathrm{~cd}$ & $0.03 \mathrm{~cd}$ & $0.05 \mathrm{~b}$ \\
\hline $\mathrm{P} 2$ & $0.06 \mathrm{bc}$ & $0.03 \mathrm{~d}$ & $0.06 \mathrm{bc}$ & $0.05 \mathrm{~b}$ \\
\hline P3 & $0.08 \mathrm{ba}$ & $0.09 \mathrm{a}$ & $0.05 \mathrm{~cd}$ & $0.07 \mathrm{a}$ \\
\hline P4 & $0.03 \mathrm{~cd}$ & $0.06 \mathrm{bc}$ & $0.06 \mathrm{bc}$ & $0.05 \mathrm{~b}$ \\
\hline Average & $0.06 \mathrm{a}$ & $0.06 \mathrm{a}$ & $0.05 \mathrm{a}$ & \\
\hline
\end{tabular}

Note: The mean values in the same column and row followed by the different letter indicates significantly different $(\mathrm{P}>0.05) . \mathrm{T} 1=$ cacao-monoculture with weeding practice, $\mathrm{T} 1=$ upland rice + soybeans between main cacao plants, and $\mathrm{T} 3+A$ pinto $i$ strip. $\mathrm{P} 1=$ slope $10-15 \%$ and $5-7$ months, $\mathrm{P} 2=$ slope $10-15 \%$ and $25-27$ months, $\mathrm{P} 3=40-50 \%$ and 5-7 months, and $\mathrm{P} 4=40-50 \%$ and $25-27$ months. 
Table 4. The $\mathrm{P}_{2} \mathrm{O}_{5}$ in soil and sediment as response to soil conservation treatment.

\begin{tabular}{|c|c|c|c|c|}
\hline Treatments & T1 & $\mathrm{T} 2$ & T3 & Average \\
\hline & \multicolumn{4}{|c|}{. } \\
\hline P1 & 21.12 & 22.95 & 24.34 & $22.80 \mathrm{a}$ \\
\hline $\mathrm{P} 2$ & 22.52 & 24.98 & 28.35 & $25.28 \mathrm{a}$ \\
\hline $\mathrm{P} 3$ & 24.10 & 29.04 & 28.66 & $27.27 \mathrm{a}$ \\
\hline $\mathrm{P} 4$ & 21.81 & 22.53 & 27.52 & $23.35 \mathrm{a}$ \\
\hline \multirow[t]{2}{*}{ Average } & $22.39 \mathrm{~b}$ & $24.87 \mathrm{ba}$ & $27.22 \mathrm{a}$ & \\
\hline & \multicolumn{4}{|c|}{$\ldots \ldots \ldots \ldots \ldots \ldots \ldots \ldots \ldots \mathrm{P}_{2} \mathrm{O}_{5}$ of sediment $\left(\mathrm{mg} 100 \mathrm{~g}^{-1}\right) \ldots \ldots$} \\
\hline P1 & 20.40 & 26.61 & 24.22 & $23.74 \mathrm{~b}$ \\
\hline $\mathrm{P} 2$ & 24.33 & 24.35 & 22.28 & $23.66 \mathrm{~b}$ \\
\hline P3 & 34.50 & 31.21 & 34.28 & $33.33 \mathrm{a}$ \\
\hline $\mathrm{P} 4$ & 28.31 & 34.76 & 39.42 & $34.16 \mathrm{a}$ \\
\hline Average & $26.88 \mathrm{a}$ & $29.23 \mathrm{a}$ & $30.05 \mathrm{a}$ & \\
\hline
\end{tabular}

Note: The mean values in the same column and row followed by the different letter indicates significantly different $(\mathrm{P}>0.05) . \mathrm{T} 1=$ cacao-monoculture with weeding practice, $\mathrm{T} 1=$ upland rice + soybeans between main cacao plants, and $\mathrm{T} 3+$ A pintoi strip. $\mathrm{P} 1=$ slope $10-15 \%$ and $5-7$ months, $\mathrm{P} 2=$ slope $10-15 \%$ and $25-27$ months, $\mathrm{P} 3=40-50 \%$ and 5-7 months, and $\mathrm{P} 4=40-50 \%$ and $25-27$ months.

of RO and the treatment of plant age/slope had significantly effect on the $\mathrm{NO}_{2}$ content of $\mathrm{RO}$, and there was interaction between them. The highest $\mathrm{NO}_{3}$ content was found in $\mathrm{T} 2$ treatment (6.67) and the lowest was found in $\mathrm{T} 1$ treatment (5.85). The highest $\mathrm{NO}_{2}$ content was in the treatment of $\mathrm{P} 3$ (0.07) and the lowest was in $\mathrm{P} 1=\mathrm{P} 2=\mathrm{P} 4$ treatments (0.05).

\section{$\mathrm{P}_{2} \mathrm{O}_{5}$ of Soil and Sediment}

The effects from the treatment on the $\mathrm{P}_{2} \mathrm{O}_{5}$ of soil and sediment are presented in Table 4.
Table 4 shows that the treatment of conservational measures had a significant effect $(\mathrm{P}$ $<0.05$ ) on the $\mathrm{P}_{2} \mathrm{O}_{5}$ content of the soil, but had no significant effect on the $\mathrm{P}_{2} \mathrm{O}_{5}$ content of the sediment. In contrast, the treatment of plant age/ slope had a significant effect on the $\mathrm{P}_{2} \mathrm{O}_{5}$ content of sediments and no significant effect on the $\mathrm{P}_{2} \mathrm{O}_{5}$ content of the soil. The highest $\mathrm{P}_{2} \mathrm{O}_{5}$ content of soil (24.87) was in the T3 treatment and the lowest (22.39) was in the $\mathrm{T} 1$ treatment while the highest $\mathrm{P}_{2} \mathrm{O}_{5}$ content of sediment (34.16) was in the $\mathrm{P} 4$ treatment and the lowest (23.66) was in the P2 treatment.

Table 5. The $\mathrm{PO}_{4}$ and total $\mathrm{K}$ contents of $\mathrm{RO}$ in each soil conservation treatment.

\begin{tabular}{|c|c|c|c|c|}
\hline Treatments & $\mathrm{T} 1$ & $\mathrm{~T} 2$ & T3 & Average \\
\hline & \multicolumn{4}{|c|}{$\ldots . \mathrm{PO}_{4}\left(\mathrm{mg} \mathrm{L}^{-1}\right)$} \\
\hline $\mathrm{P} 1$ & 7.22 & 6.78 & 6.74 & $6.91 \mathrm{a}$ \\
\hline $\mathrm{P} 2$ & 7.02 & 7.04 & 6.42 & $6.82 \mathrm{a}$ \\
\hline P3 & 6.99 & 6.56 & 6.05 & $6.53 \mathrm{a}$ \\
\hline P4 & 6.07 & 7.32 & 7.31 & $6.90 \mathrm{a}$ \\
\hline \multirow[t]{2}{*}{ Average } & $6.82 \mathrm{a}$ & $6.92 \mathrm{a}$ & $6.63 \mathrm{a}$ & \\
\hline & \multicolumn{4}{|c|}{..Total $\mathrm{K}\left(\mathrm{mg} \mathrm{L}^{-1}\right)$} \\
\hline $\mathrm{P} 1$ & 46.67 & 49.33 & 51.00 & $49.00 \mathrm{a}$ \\
\hline $\mathrm{P} 2$ & 51.00 & 54.33 & 50.67 & $52.00 \mathrm{a}$ \\
\hline P3 & 51.00 & 55.67 & 50.67 & $52.44 \mathrm{a}$ \\
\hline $\mathrm{P} 4$ & 56.00 & 55.00 & 48.67 & $53.22 \mathrm{a}$ \\
\hline Average & $51.15 \mathrm{a}$ & $53.58 \mathrm{a}$ & $50.25 \mathrm{a}$ & \\
\hline
\end{tabular}

Note: The mean values in the same column and row followed by the same letter indicates no significantly different $(\mathrm{P}>0.05)$. $\mathrm{T} 1=$ cacao-monoculture with weeding practice, $\mathrm{T} 1=$ upland rice + soybeans between main cacao plants, and T3 + A. pintoi strip. $\mathrm{P} 1=$ slope $10-15 \%$ and $5-7$ months, $\mathrm{P} 2=$ slope $10-15 \%$ and 25-27 months, $\mathrm{P} 3=40-50 \%$ and 5-7 months, and $\mathrm{P} 4=40-50 \%$ and $25-27$ months. 
Table 6. Content of $\mathrm{K}_{2} \mathrm{O}$ in soil and sediment as response to soil conservation treatment.

\begin{tabular}{|c|c|c|c|c|}
\hline Treatments & $\mathrm{T} 1$ & $\mathrm{~T} 2$ & T3 & Average \\
\hline & \multicolumn{4}{|c|}{ 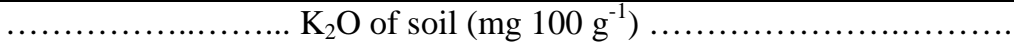 } \\
\hline P1 & 11.86 & 17.10 & 17.36 & $15.44 \mathrm{a}$ \\
\hline $\mathrm{P} 2$ & 9.85 & 14.13 & 15.73 & $13.23 \mathrm{a}$ \\
\hline P3 & 11.79 & 13.37 & 15.52 & $13.55 \mathrm{a}$ \\
\hline $\mathrm{P} 4$ & 12.48 & 16.08 & 15.92 & $14.83 \mathrm{a}$ \\
\hline Average & $11.50 \mathrm{a}$ & $15.16 \mathrm{~b}$ & $16.13 \mathrm{c}$ & \\
\hline & \multicolumn{4}{|c|}{ 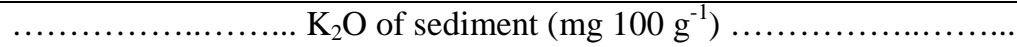 } \\
\hline P1 & 17.63 & 23.08 & 24.15 & $21.62 \mathrm{a}$ \\
\hline $\mathrm{P} 2$ & 12.03 & 12.03 & 18.49 & $14.18 \mathrm{~b}$ \\
\hline P3 & 21.02 & 17.36 & 20.02 & $19.47 \mathrm{a}$ \\
\hline $\mathrm{P} 4$ & 20.88 & 23.32 & 21.02 & $21.74 \mathrm{a}$ \\
\hline Average & $17.89 \mathrm{a}$ & $18.95 \mathrm{a}$ & $20.92 \mathrm{a}$ & \\
\hline
\end{tabular}

Note: The mean values in the same column and row followed by the different letter indicates significantly different $(\mathrm{P}>0.05)$. $\mathrm{T} 1=$ cacao-monoculture with weeding practice, $\mathrm{T} 1=$ upland rice + soybeans between main cacao plants, and $\mathrm{T} 3+$ A. pintoi strip. $\mathrm{P} 1=$ slope 10 $15 \%$ and 5-7 months, $\mathrm{P} 2=$ slope $10-15 \%$ and $25-27$ months, $\mathrm{P} 3=40-50 \%$ and $5-7$ months, and $\mathrm{P} 4=40-50 \%$ and $25-27$ months.

\section{$\mathrm{PO}_{4}$ and Total $\mathrm{K}$ of the Run Off}

The phosphate that was measured at the RO was in the form of $\mathrm{PO}_{4}$, whereas the potassium that was measured was the total $\mathrm{K}$. The average $\mathrm{PO}_{4}$ and total $\mathrm{K}$ content of $\mathrm{RO}$ in each treatment are presented in Table 5.

The results of the analysis of variance show that the treatment had no significant effect $(\mathrm{P}<0.05)$ on $\mathrm{PO}_{4}$ and total $\mathrm{K}$ content of $\mathrm{RO}$.

\section{$\mathrm{K}_{2} \mathrm{O}$ content of Soil and Sediment}

The effect of treatments on the $\mathrm{K}_{2} \mathrm{O}$ content of soil and sediment are presented in Table 6 .

The $\mathrm{K}_{2} \mathrm{O}$ content of the soil in Table 5 indicates significant by differences $(\mathrm{P}<0.05)$ which were caused by the treatment of conservational measures, but no apparent differences which were caused by the treatment of plant age/slope. In contrast, it occured in the $\mathrm{K}_{2} \mathrm{O}$ content of sediments. The highest $\mathrm{K}_{2} \mathrm{O}$ content of soil (16.13) as a result of conservational measures was in the $\mathrm{T} 3$ treatment and the lowest (11.50) was found in the T1 treatment. The highest $\mathrm{K}_{2} \mathrm{O}$ content (21.74) as a result of the plant age/slope treatment was in the P4 treatment and the lowest (14.18) was in the P2 treatment.

\section{C-organic Content of Soil, Sediment, and Run Off}

The effects of treatments on organic-C of soil, sediment, and RO are presented in Table 7.
The results of the analysis of variance on the organic-C of soil indicated that the treatment of conservational measures had a significant effect $(\mathrm{P}$ $<0.05$ ) in increasing organic-C in soil, as well as the treatment of plant age/slope, but there was no interaction between them. Conservational measures (T3) provided the highest organic-C in soil (2.00) and was significantly different from T2 (1.73), but had not shown significant differences in T1 (1.82) based on the t-test at a level of 0.05. As for the treatment of plant/slope, $\mathrm{P} 4$ provided the highest organic-C in soil (2.11) and was significantly different from other treatments.

Organic-C and RO based on the results of the analysis of variance did not differ significantly $(\mathrm{P}<$ 0.05 ) with the treatment given, whether it was the treatment of conservational measures or the plant age/slope treatment.

\section{Sediment Enrichment Ratio (SER)}

SER is a comparison between the concentrations of nutrients (or organic matter) in sediments that have been transported along the RO with the concentrations of nutrient (or organic matter) in the soil left behind. The effects of treatment towards the NPS are presented in Table 8.

The results of the analysis of variance towards the sediment enrichment ratio indicated that the plant age/slope treatment had a significant effect $(\mathrm{P}>$ 0.05 ) on the SER, but conservational measures had not shown visible effect on the SER. The plant/slope treatment (P4) gave the highest value of NPS (1.62) 
Table 7. Organic-C content of soil, sediment and RO in response to soil conservation treatment.

\begin{tabular}{|c|c|c|c|c|}
\hline Treatments & $\mathrm{T} 1$ & $\mathrm{~T} 2$ & T3 & Average \\
\hline & \multicolumn{4}{|c|}{ f........................ Organic-C of soil $(\%) \ldots$} \\
\hline $\mathrm{P} 1$ & 1.72 & 1.61 & 1.78 & $1.70 \mathrm{~b}$ \\
\hline $\mathrm{P} 2$ & 2.00 & 1.56 & 1.87 & $1.81 \mathrm{~b}$ \\
\hline P3 & 1.62 & 1.71 & 2.00 & $1.78 \mathrm{~b}$ \\
\hline $\mathrm{P} 4$ & 1.96 & 2.03 & 2.35 & $2.11 \mathrm{a}$ \\
\hline \multirow[t]{2}{*}{ Average } & $1.82 \mathrm{~b}$ & $1.73 \mathrm{ba}$ & $2.00 \mathrm{~b}$ & \\
\hline & \multicolumn{4}{|c|}{$\ldots$} \\
\hline $\mathrm{P} 1$ & 1.80 & 1.84 & 1.69 & $1.78 \mathrm{a}$ \\
\hline $\mathrm{P} 2$ & 1.91 & 1.74 & 1.84 & $1.83 \mathrm{a}$ \\
\hline P3 & 2.46 & 1.75 & 1.80 & $2.00 \mathrm{a}$ \\
\hline $\mathrm{P} 4$ & 2.10 & 2.15 & 2.29 & $2.18 \mathrm{a}$ \\
\hline \multirow[t]{2}{*}{ Average } & $2.07 \mathrm{a}$ & $1.87 \mathrm{a}$ & $1.91 \mathrm{a}$ & \\
\hline & \multicolumn{4}{|c|}{ Organic-C of RO $(\%) \ldots \ldots .}$. \\
\hline P1 & 0.46 & 0.41 & 0.55 & $0.48 \mathrm{a}$ \\
\hline $\mathrm{P} 2$ & 0.54 & 0.55 & 0.50 & $0.53 \mathrm{a}$ \\
\hline P3 & 0.51 & 0.52 & 0.44 & $0.49 \mathrm{a}$ \\
\hline $\mathrm{P} 4$ & 0.57 & 0.54 & 0.47 & $0.53 \mathrm{a}$ \\
\hline
\end{tabular}

Note: The mean values in the same column and row followed by the different letter indicates significantly different $(\mathrm{P}>0.05)$. $\mathrm{T} 1=$ cacao-monoculture with weeding practice, $\mathrm{T} 1=$ upland rice + soybeans between main cacao plants, and $\mathrm{T} 3+$ A pintoi strip. $\mathrm{P} 1=$ slope $10-15 \%$ and $5-7$ months, $\mathrm{P} 2=$ slope $10-15 \%$ and $25-27$ months, $\mathrm{P} 3=40-50 \%$ and $5-7$ months, and $\mathrm{P} 4=40-50 \%$ and $25-27$ months.

Table 8. Sediment enrichment ratio (SER) in response to soil conservation treatment.

\begin{tabular}{ccccc}
\hline Treatments & T1 & T2 & T3 & Average \\
\hline P1 & 1.34 & 1.37 & 1.31 & $1.34 \mathrm{c}$ \\
P2 & 1.31 & 1.28 & 1.09 & $1.23 \mathrm{c}$ \\
P3 & 1.73 & 1.31 & 1.37 & $1.47 \mathrm{a}$ \\
P4 & 1.62 & 1.69 & 1.54 & $1.62 \mathrm{a}$ \\
\hline Average & $1.50 \mathrm{a}$ & $1.41 \mathrm{a}$ & $1.33 \mathrm{a}$ & \\
\hline
\end{tabular}

Note: The mean values in the same column and row followed by the different letter indicates significantly different $(\mathrm{P}>0.05)$. $\mathrm{T} 1=$ cacao-monoculture with weeding practice, $\mathrm{T} 1=$ upland rice + soybeans between main cacao plants, and $\mathrm{T} 3+$ A. pinto $i$ strip. $\mathrm{P} 1=$ slope $10-15 \%$ and $5-7$ months, $\mathrm{P} 2=$ slope $10-15 \%$ and $25-27$ months, $\mathrm{P} 3=40-50 \%$ and 5-7 months, and $\mathrm{P} 4=40-50 \%$ and $25-27$ months.

and is significantly different from P1 (1.34) and T2 (1.23), but not significantly different from P3 (1.47).

\section{Discussion}

T3 treatment had the highest total $\mathrm{N}, \mathrm{P}_{2} \mathrm{O}_{5}$, and $\mathrm{K}_{2} \mathrm{O}$ of soil compared to other treatments whereas the lowest total $\mathrm{N}, \mathrm{P}_{2} \mathrm{O}_{5}$, and $\mathrm{K}_{2} \mathrm{O}$ of soil was found in the $\mathrm{T} 1$ treatment. High contents of total $\mathrm{N}, \mathrm{P}_{2} \mathrm{O}_{5}$, and $\mathrm{K}_{2} \mathrm{O}$ in soil from the $\mathrm{T} 3$ treatment was due to the fertilizing of seasonal crops and the inhibiting of RO (strip A. pintoi) that suppressed the loss of nutrients transported along the run-off and erosion. While on $\mathrm{T} 1$ treatment, the planting of seasonal crops was not done causing it did not have residual fertilizer from the fertilizing of seasonal crops which could increase the content of soil nutrient. In the T2 treatment, although the fertilizing of seasonal crops was done, but it was not accompanied by the strip of plants that could inhibit RO and erosion causing the soil to have lower level of nutrients compared to the $\mathrm{T} 3$ treatment. Cross-slope cultivated and residue corporation and mulching can reduce total $\mathrm{RO}$ (reduced RO coefficient) and quickflow, while increasing and prolonging delayed flow(Sinukaban et al. 2007).

In line with the research results of Udwatta et al. (2002), the annual intercropping system, using 
maize and soybean plants with grass strips in the same direction with the contour, had an influence on the RO, sediment and nutrient release. This system, after three years, had reduced RO and the release of total phosphorus as much as 1 and $17 \%$, respectively, while the treatment of grass strips in the same direction with the contour had reduced $\mathrm{RO}$ and total phosphorus as much as 10 and $8 \%$, respectively.

The highest organic-C content of soil was found in the T3 treatment and the lowest was found in the $\mathrm{T} 1$ treatment. The high value of organic-C in T3 treatment was due to the contribution of organic matter from annual crops, perennial crops, and the results of A. Pintoi clipping. Organic matter improves soil fertility, both physically and chemically. In the improvement of chemical fertility, especially through nutrient recycling where nutrients are not absorbed by the roots of crops and leached into the deeper layers of soil with percolation water, those nutrients will be absorbed by the roots of annual plant and will be returned to the top soil in the form of organic matter.

The contents of total $\mathrm{N}, \mathrm{P}_{2} \mathrm{O}_{5}, \mathrm{~K}_{2} \mathrm{O}$, and organic-C of soil was low in organic-C of sediment and RO, which was indicated by the value of SER $>1$. This is because the eroded soil is the topsoil which is rich in nutrients and organic matter. As stated by Arsyad (2010), the content of nutrients and organic matter in sediments as a result of erosion is higher than the content of nutrients and organic matter in soils that are left behind. Schiettecatte et al. (2008) reported that enrichment of organic-C in suspended sediment is dependent on the erosion process.

This is partly due to the selectivity of the erosion and partly caused by the topsoil having higher content of nutrient than the lower layers of soil. Furthermore, Sutono et al. (2005) has brought forward that the $\mathrm{P}_{2} \mathrm{O}_{5}$ and $\mathrm{K}_{2} \mathrm{O}$ carried away by erosion is much higher than that carried by the AP and the amount that has been eroded is higher than the residue that remains in the soil.

\section{CONCLUSIONS}

The amount of total $\mathrm{N}, \mathrm{P}_{2} \mathrm{O}_{5}, \mathrm{~K}_{2} \mathrm{O}$ and organic$\mathrm{C}$ that was carried away with the sediments and the $\mathrm{RO}$ was higher than the amount of total $\mathrm{N}, \mathrm{P}_{2} \mathrm{O}_{5}$, $\mathrm{K}_{2} \mathrm{O}$, and Organic-C that remains in the soil which was indicated by the enrichment ratio Sediment $>$ 1. Conservational measures treatment provided a higher contents of total- $\mathrm{N}, \mathrm{P}_{2} \mathrm{O}_{5}$, and $\mathrm{K}_{2} \mathrm{O}$ of soil compared to other treatments.
In general, the research has not shown differences in nutrient levels of sediment and run-off in response to the treatment of conservational measures. For that reason, the research should be continued to see the more significant effect of treatment on the leaching of nutrients. Because these relatively simple changes to current practice are new for farmers in the region their adoption might be a problem. Therefore, demonstration plots and extension activity are being carried out as result of this study, and the conservation farming system is the key for farmers empowerment and sustainable agriculture development.

\section{ACKNOWLEDGEMENTS}

We thank to the Indonesian Directorate General of Higher Education (DGHE), Ministry of National Education Republic of Indonesia which had provided funding to conduct competitive Grant research for Fiscal Year 2008.

\section{REFERENCES}

Abdullah TS. 2006. Buku lapang untuk pendeskripsian dan pengambilan contoh tanah berdasarkan taksonomi tanah USDA. Departmen Ilmu Tanah dan Sumberdaya Lahan Fakultas Pertanian IPB. Bogor (in Indonesian).

Alvim PdeT. 1977. Ecological and physiological determinant of cacao yield. In: Proceedings of the $5^{\text {th }}$ International Cacao Research Conference, Ibadan Nigeria, pp. 25-28.

Arsyad S. 2010. Konservasi Tanah dan Air. Edisi ke-2 Cetakan ke-2. IPB- Press. Bogor (in Indonesian).

Mattjik AA and M Sumertajaya. 2002. Perancangan percobaan dengan aplikasi dan minitab. Jilid I. IPBPress. Bogor (in Indonesian).

Schiettecatte W, D Gabriels, WM Cornelis and G Hofman. 2008. Enrichment of organic carbon in sediment transport by interrill and rill erosion processes. Soil Sci Soc Am J 72 (1): 50-55.

Sinukaban N. 2007. Potential pollution of surface and ground water in wetland rice and vegetable production areas in Indonesia. Soil and Water Conservation in Sustainable Development. Publised by DITJEN RLPS. Dept. Kehutanan, $1^{\text {st }}$ edition, pp. 92-96.

Sinukaban N. 2007a. Deforestation of tropical rainforest and soil degradation in transmigration area, Indonesia. Soil and Water Coservation in Sustainable Development. Publised by DITJEN RLPS, Dept. Kehutanan, ${ }^{\text {st }}$ edition, pp. 26-34.

Sinukaban N, H Pawitan, S Arsyad and J Amstrong. 2007. Impact of soil and water conservation practices on stream flows in cinere catchments, west-java, Indonesia. Soil and Water Conservation in Sustainable Development. Publised by DITJEN RLPS, Dept. Kehutanan, $1^{\text {st }}$ edition, pp. 63-71. 
Sutandi A. 2006. Penuntun praktikum analisis tanah. Departmen Ilmu Tanah dan Sumberdaya Lahan Fakultas Pertanian IPB. Bogor (in Indonesian).

Sutono S, MS Djunaedi, D Erfandi and U Kurnia. 2005. Pengangkutan hara oleh erosi, aliran permukaan, perkolasi, dan tanaman cabai rawit. Prosiding Seminar Nasional Inovasi Teknologi Sumberdaya Tanah dan Iklim, 14-15 September 2004. Departemen Pertanian, Balai Penelitian dan Pengembangan Tanah dan Agroklimat, Bogor, pp. 97-121 (in Indonesian).

Suwardi and H Wiranegara. 2000. Penuntun praktikum morfologi dan klasifikasi tanah. Departmen Ilmu Tanah dan Sumberdaya Lahan Fakultas Pertanian IPB. Bogor (in Indonesian).
Udawatta RP, JJ Krstansky, GS Handerson and HE Garrent. 2002. Agroforestry Practices, Runoff, and Nutrient Loss: A Paired Watershed Comparison. $J$ Environ Qual 31: 1214-1222.

Wahab A, M Sjafaruddin and Sahard. 2002. Status bahan organik tanah pada perkebunan kakao di kabupaten Kolaka Sulawesi Tenggara. Prosiding Seminar Nasional BPTP Sultra, Kendari 6-7 Agustus 2002, pp 451-459 (in Indonesian).

Wischmeier WH and DD Smith. 1978. Predicting rainfall erosion losses. A Guide to Conservation Planning. USDA. Agric Eng 29: 458-462.

Zuidema PA, PA Leûelaar, W Gerritsma, L Mommer and NPR Anten. 2005. A physiological production model for cocoa(Theobroma cacao): model presentation, validation and application. Agric Syst 84: 195-225. 